\title{
WARTAWAN DAN BUDAYA AMPLOP (BUDAYA AMPLOP PADA WARTAWAN PENDIDIKAN DALAM KAITANNYA DENGAN MEDIA RELATIONS)
}

\author{
Adhianty Nurjanah (adhianty.nurjanah@yahoo.co.id) \\ Wulan Widyasari (wulan_widyasari@yahoo.com) \\ Frizki Yulianti Nurnisya (friskinurnisya@gmail.com) \\ Program Studi Ilmu Komunikasi \\ Universitas Muhammadiyah Yogyakarta
}

\begin{abstract}
Journalists play an important role as the fourth pillar of democracy. Doing so, journalists should be independent and separated from outside interference. This independence is not only applied to the relationship of journalistandthe government, but also applied to the relationship of journalists and news sources such as higher education institutions. In obtaining the proclamation of higher education institutions, journalists often intersect with public relations practitioners who also perform the task of media relations to gain publicity. This study aims to determine how to deal with the envelope cultureof journalists conducted by public relations practitioners of higher education institutions in Yogyakarta. The method used in this research is descriptive qualitative using interviews and focus group discussions on five journalists from famous print media in Yogyakarta, namely Kompas, Tribun, Harian Jogja, Kedaulatan Rakyat and Radar Jogja. The results of this study show that a good relationship between journalists and public relations practitioners play an important role in preventing the envelope culture and also, public relations practitioners need to have an understanding of newsworthy issues. In addition, journalismethics (KEJ) from the journalist associations can also be used as a strong reference in relation to the ban the envelope culture among journalists.
\end{abstract}

\begin{abstract}
Abstrak
Wartawan memainkan peranan penting sebagai pilar ke-4 dalam demokrasi. Untuk itu wartawan harus bersikap independen dan terlepas dari intervensi pihak luar. Independensi ini tidak hanya berlaku pada hubungan wartawan dengan pemerintah saja, namun juga berlaku pada hubungan wartawan dengan sumber beritanya seperti institusi pendidikan tinggi. Dalam memperoleh pemberitaan dari institusi pendidikan tinggi, wartawan sering kali bersinggungan dengan praktisi public relations yang juga melakukan tugas media relations untuk memperoleh publikasi. Penelitian ini bertujuan untuk mengetahui bagaimana para wartawan menyikapi budaya amplop yang dilakukan oleh praktisi public relations institusi pendidikan tinggi di Yogyakarta. Metode penelitian yang digunakan dalam penelitian ini adalah deskriptif kualitatif dengan melakukan wawancara dan FGD pada lima orang wartawan dari media cetak di Yogyakarta, yaitu Kompas, Tribun, Harian Jogja, Kedaulatan Rakyat dan Radar Jogja. Hasil dari penelitian ini menunjukkan bahwa relasi yang baik antara wartawan dan praktisi public relations memainkan peranan penting dalam mencegah adanya budaya amplop dan perlu adanya strategi pengolahan isu yang bernilai berita. Selain itu, Kode Etik Jurnalistik (KEJ) yang dicetuskan asosiasi wartawan juga dapat dijadikan acuan yang kuat dalam kaitannya dengan larangan budaya amplop di kalangan wartawan.
\end{abstract}

Keywords: Journalist, Envelope Culture, Journalism Ethics 


\section{PENDAHULUAN}

Luwi Ishwara, wartawan senior Kompas menyatakan bahwa demokrasi sebuah negara bisa terus berjalan dan lestari jika masyarakatnya mendapat informasi valid dan transparan untuk menimbang dan memutuskan opini ataupun tindakan yang akan ia lakukan kepada publik terkait kepentingan bersama. Salah satu sumber informasi tersebut ialah melalui laporan berita pewarta di media massa. Ini berarti wartawan menanggung beban tugas demokratik (democratic duty) untuk menulis berita secara jelas sehingga mudah dipahami publik. Ishwara (2011: 3) menulis bahwa wartawan mempunyai kontrak sosial yang paralel. Maksudnya, jika wartawan bisa menjalankan tugasnya dengan baik maka proses demokrasi akan terus berjalan.

Dalam konteks Indonesia, mantan hakim Mahkamah Konstitusi, Jimly Asshiddiqie dalam web resminya menyatakan bahwa pers sebagai pilar keempat demokrasi, juga telah dijamin kemerdekaannya dan diakui keberadaannya oleh UUD 1945, seperti halnya tiga pilar demokrasi lainnya, yakni kekuasaan eksekutif, legislatif, dan yudikatif. Salah besar anggapan orang jika kebebasan pers tidak terdapat dalam UUD, karena salah satu roh demokrasi ialah kebebasan berekspresi dan itu dekat dengan kebebasan pers.

Sebagai salah satu dari pilar demokrasi, pers memiliki tanggung jawab untuk juga meningkatkan profesionalisme. Selain itu, Jimly menyatakan dalam negara hukum, salah satu roh dari rule of law adalah profesionalisme sehingga agar dapat berjalan, demokrasi memerlukan prasyarat sosial, yakni kaum profesional yang menjadi jembatan (intermediate structure) antara masyarakat kelas bawah dengan kaum elit, dan salah satu kaum profesional kelas menengah ini adalah wartawan (http://www.jimly.com/kegiatan/ show/151, diakses 16 Agustus 2015 pukul. 21.22).

Dalam rangka menjaga profesionalisme para wartawan maka perlu dibentuk sebuah aturan yang sifatnya mengikat profesi wartawan sehingga Persatuan Wartawan Indone- sia (PWI) dan Aliansi Jurnalis Indonesia (AJI) akhirnya menyusun Kode Etik Jurnalistik untuk wartawan Indonesia. Hal yang terpenting ialah setiap orang yang berprofesi sebagai wartawan harus berada di bawah naungan Kode Etik Jurnalistik karena kode etik yang dirancang perkumpulan wartawan merupakan pengungkapan kontrak yang dibuat wartawan demi kepentingan bersama.

Setelah dirancang dan diresmikan sebuah Kode Etik Jurnalistik dalam sebuah peraturan hitam di atas putih maka setiap wartawan harus konsekuen dan berpegang teguh mematuhi peraturan tersebut, sedangkan dewan kehormatan pers juga harus terus melaksanakan pengawasan secara terus menerus karena kode etik tersebut tentu memiliki konsekuensi bagi pelanggarnya, misalkan sanksi moral ataupun sanksi dikeluarkan dari organisasi. Akan tetapi dalam implementasinya, penerapan kode etik profesi wartawan ini tidak berjalan dengan baik, entah karenanya minimnya pengawasan baik pengawasan dewan pers terhadap anggotannya, pengawasan wartawan terhadap koleganya, bahkan ketiadaan pengawasan wartawan terhadap dirinya sendiri.

Kealpaan ini berimplikasi pada Kode Etik profesi Wartawan dianggap hanya sebagai tempelan semata, tidak memiliki kekuatan mengikat bagi anggotanya.Padahal salah satu tujuan kode etik profesi ini ialah menjunjung tinggi martabat serta menjadi standarisasi bagi pewarta.Amat disayangkan jika wartawan menjalankan profesinya tanpa mengetahui standar pelaksaan profesinya.

Wartawan sebenarnya memainkan banyak perannya sendiri. Beynard C. Cohen menyatakan salah satu peran pewarta ialah sebagai penginformasi (informer) yang akan menjadi mata telinga masyarakat kemudian menginformasikan kepada masyarakat dengan netral dan tanpa prasangka apapun. Selain berperan sebagai penginformasi (informer) ataupun pelapor (reporter), para pewarta ini juga menjadi penerjemah (interpreter) sebelum melaporkan sebuah peristiwa maka akan memperkaya berita tersebut dengan memverifikasi beberapa sumber berita sehingga menjadi laporan yang men- 
dalam kemudian "membumikan" bahasa agar mudah dimengerti oleh khalayaknya. Akan tetapi, peran terpenting dari seorang wartawan ialah peran wartawan sebagai watchdog yakni pengawas yang akan mengkritik kebijakan pihak yang berwenang atas kepentingan banyak orang. Setiap wartawan akan diberikan kemampuan intelejen untuk menganalisis apakah ada pejabat publik yang menyalahgunakan wewenangnya, ataukah adakah hak masyarakat sipil yang dicurangi, ataukah ada kongkalingkong sekelompok oknum, sehingga banyak pihak-pihak mengkhawatirkan keberadaan wartawan yang menyajikan berita secara "jujur apa adanya".

Kini banyak orang yang berusaha dengan berbagai cara untuk "menjinakkan" para watchdog dan tidak sedikit yang berhasil mengubah wartawan menjadi lapdog yang "lucu dan patuh" bagi tuan-tuannya. Menyampaikan berita didasarkan atas keinginan tuannya dan tidak mampu bersifat kritis karena sudah dipengaruhi oleh banyak kepentingan, entah itu kepentingan politik ataupun kepentingan bisnis semata. Bisa jadi mereka lupa bahwa mereka punya beban tugas memegang teguh demokrasi ketika menjalankan profesinya.

Dalam sebuah penelitian skripsi yang disusun oleh mahasiswa Ilmu Komunikasi Universitas DipononegoroSemarang, Choirul Ulil Albab, dengan judul Penataan Kode Etik Jurnalis Peliput Pemerintah Provinsi Jawa Tengah Setelah Penghapusan Amplop Jurnalis, ditemukan bahwa salah satu cara untuk "menjinakkan" wartawan ialah dengan memberikan amplop. Nominal yang diberikan oleh Pemprov Jawa Tengah ialah Rp 150.00o,oo/ wartawan, namun semenjak Ganjar Pranowo dilantik menjadi Gubernur Jawa Tengah maka kebijakan amplop tersebut dihapuskan karena dikhawatirkan akan mempengaruhi independensi dan netralitas wartawan ketika melakukan peliputan di kawasan Pemerintah Provinsi Jawa Tengah.

Pemberian amplop kepada jurnalis seringkali dimaksudkan untuk menjalin silahturahim yang positif dengan wartawan.Akan tetapi memiliki sisi negatif karena mengandung kecurigaan maksud terselubung baik bagi si pemberi maupun si penerima.Meskipun diakui oleh wartawan bahwa pemberian amplop kepada wartawan bukanlah hal yang baru malah sulit dilepaskan dari dunia jurnalistik karena memang sudah membudaya. Akhirnya pemberian amplop kepada wartawan ini terjadi seperti biasa yang berlangsung secara terus menerus.

Pemberian amplop kepada wartawan pada akhirnya juga menimbulkan dualisme di kalangan wartawan sendiri. Sebagian merasa hal tersebut adalah hal yang merendahkan profesi wartawan, namun tidak sedikit yang menganggap amplop tersebut hanyalah bentuk silahturahim dari instansi dan tentu tidak akan mennggangu proses netralitas pemberitaan di medianya.

Sama halnya dengan praktisi public relations di sebuah instansi baik pemerintah maupun swasta.Wartawan sebagai partner untuk memposisikan instansi secara positi tentu harus mendapatkan hospitality yang prima dari setiap praktisi public relations. Keberaadaan wartawan akan memudahkan pekerjaaan praktisi public relations yang ingin menjangkau audience sebanyak mungkin dengan waktu yang hampir bersamaan. Apalagi ditambah dengan fakta bawa wartawan melalui medianya, bisa dianggap sebagai 'orang ketiga" dari perusahaan yang memiliki tingkat kepercayaan lebih tinggi dibandingkan oleh humasnya sendiri.

Praktisi public relations tentu telah melakukan berbagai macam kegiatan media relations demi membangun hubungan simbiosis mutualisme dengan rekan wartawan, misalkan dengan melakukan pers briefing, press release, pres tour, resepsi pers dan wawancara pers. (Soemirat, 2007: 128-129). Melalui kegiatan media relations ini tentu akan memberikan pencitraan positif bagi institusi. Pengaruh media massa sebagai sumber informasi masyarakat semakin memudahkan pekerjaan praktisi public relations yang ingin terus menerus mengabarkan kepada khalayak mengenai kesuksesan organisasinya. Sama halnya ungkapan fenomenal Abraham Lincoln "public opinion is everything" maka jika seluruh media massa mengungkapkan perusahaan Anda baik maka 
tentu publik akan percaya bahwa perusahaan Anda baik, namun begitupun sebaliknya jika seluruh media massa mengatakan perusahaan Anda buku maka publik akan percaya bahwa perusahaan Anda buruk.

Begitupun dengan praktisi public relations institusi pendidikan tinggi yang mulai menyadari peran pekerja media sebagai partner yang dapat membantu mencapai tujuan organisasinya untuk membangun image positif di masyarakat. Merekapun mulai menyusun strategi media relations agar bisa lebih akrap dengan rekan wartawan yang biasa meliput di instansinya. Akan tetapi kegiatan mereka menganggap cara terbaik untuk menjalin hubungan baik dengan rekan wartawan ialah dengan memberikan fasilitas berupa uang tunai / amplop. Padahal menurut kode etik profesi wartawan setiap jurnalis dilarang untuk menerima uang. Pemberian uang tunai atau "amplop" bagi wartawan kemudian membudaya hampir pada semua aktivitas media relations yang dilakukan oleh praktisi public relations institusi pendidikan tinggi di Yogyakarta.

Dari penjelasan di atas, penulis ingin meneliti lebih jauh, bagaimana para wartawan menyikapi budaya amplop yang dilakukan oleh praktisi public relations institusi pendidikan tinggi di Yogyakarta, termasuk kemungkinan adanya budaya amplop dalam kegiatan media relations yang selama ini dilakukan oleh praktisi public relations tersebut.

\section{METODE}

Penelitian ini termasuk kedalam jenis penelitian deskriptif kualitatif. Penelitian deskriptif menurut Whitney (dalam Nazir, 1988: 63) yaitu penelitian untuk pencarian fakta dengan interpretasi yang tepat. Mempelajari masalah-masalah dalam masyarakat, serta tatacara masyarakat serta situasi-situasi tertentu, termasuk tentang hubungan kegiatan-kegiatan, sikap-sikap, pandanganpandangan serta proses-proses yang sedang berlangsung dan pengaruh-pengaruh dari suatu fenomena. Tujuan dari penelitian ini adalah untuk membuat deskripsi, gambaran atau lukisan secara sistematis, faktual dan akurat mengenai fakta-fakta, sifat-sifat serta hubungan antar fenomena yang diselidiki. Penelitian ini menggunakan metode studi kasus, metode studi kasus adalah memberikan gambaran secara mendetail tentang latar belakang, sifat-sifat serta karakter yang khas dari kasus, dari sifat-sifat khas tersebut akan dijadikan suatu hal yang bersifat umum. (Nazir, 1988:66).

Sedangkan teknik pengumpulan data dalam penelitian ini, peneliti menggunakan beberapa cara yaitu:

a. Interview (wawancara)

Wawancara adalah proses memperoleh keterangan untuk tujuan penelitian dengan cara tanya jawab sambil bertatap muka anatara si penanya dengan si penjawab atau responden dengan menggunakan panduan wawancara atau interview guide (Nazir, 1988: 234).

b. Dokumentasi

Dokumentasi adalah kegiatan mengumpulkan data dengan memanfaatkan semua dokumen-dokumen penting yang menyangkut perusahaan secara umum, misalnya company profile, web site perusahaan, media internal dan lain-lain.

c. Studi pustaka

Penelitian ini dilakukan dengan menggunakan buku-buku sebagai sumber data dan acuan teori yang berhubungan dengan penelitian yang diambil yaitu mengenai Public Relations dan Media Relations.

d. Focus Group Discussion (FGD)

Merupakan metode penelitian dimana menggunakan kelompok diskusi terfokus dengan memilih orang-orang yang dianggap mewakili sejumlah publik atau populasi yang berbeda.

Data dalam penelitian ini akan dianalisis secara kualitatif. Penelitian kualitatif merupakan suatu prosedur yang menghasilakan data deskriptif berupa kata tertulis, atau lisan orang-orang atau perilaku yang diamati (Moleong, 2001: 103).Analisis data yang bersifat kualitatif mengharuskan peneliti untuk melakukan aktivitas secara serempak den- 
gan pengumpulan data, interpretasi data dan menulis laporan penelitian (Creswell, 1994: 145). Dengan demikian analisis data tidak dilakukan secara terpisah dengan pengumpulan data, tetapi merupakan kegiatan yang dilakukan bersama-sama. Teknik yang dilakukan dalam uji validitas data yaitu dengan teknik triangulasi. Menurut Moleong (2001: 178), triangulasi adalah teknik pemeriksaan keabsahan data yang memanfaatkan sesuatu lain diluar data itu untuk keperluan pengecekan atau sebagai pembanding terhadap data itu.

Dalam penelitian ini, peneliti mengunakan triangulasi sumber. Menurut Patton (dalam Moleong, 2001: 178) menyebutkan triangulasi dengan sumber berarti membandingkan dan mengecek balik derajat kepercayaan suatu informasi yang diperoleh melalui waktu dan alat yang berbeda dalam metode kualitatif.

Penulis memilih lima (5) wartawan media cetaknya adalah wartawan yang ditugaskan di desk pendidikan pada saat penelitian ini berlangsung diantaranya adalah Haris Firdaus (Kompas), Rahajeng (Kedaulatan Rakyat), Laela Rohmatin (Harian Jogja), Pristiqa A.Wirastami (Tribun Jogja) dan Heditia Damanik (Radar Yogya).

\section{HASIL DAN PEMBAHASAN}

\section{Peran Penting Relasi Wartawan dan Praktisi Public Relations}

Selama ini, relasi wartawan dan praktisipublic relations institusi pendidikan tinggi sering kali disepelekan. Padahal sikap saling percaya dan saling membutuhkan memainkan peranan penting bagi wartawan. Artinya, wartawan dan praktisi public relations bisa saling bekerja sama untuk memenuhi tuntutan tugas masing-masing. Menurut hasil FGD yang dilakukan, praktisi public relations hanya memerankan diri sebagai marketinginstitusi saja. Praktisi public relationsbiasanya akan menghubungi wartawan jika ada kegiatan yang membutuhkan publikasi.

"Ketika ada berita negatif, wartawan sering ditutup aksesnya yang akibatnya hubungan jangka panjang menjadi jelek. Wartawan tidak ingin dimanfaatkan oleh PR ketikadibutuhkan saja." (wawancara dengan Haris Firdaus)

Maksud dari relasi di sini bukan berarti adanya intervensi praktisi public relations pada pemberitaan yang dilakukan oleh wartawan, namun lebih kepada pemberian akses yang luas dan informasi yang terbuka kepada wartawan mengenai pemberitaan yang diliputnya. Bill Kovach dan Tom Rosenstiel pernah menyebutkan bahwa wartawan harus tetap bersikap independent terhadap objek yang diliputnya (Kovach dan Rosenstiel, 2001: 12). Artinya, pihak lain tidak boleh melakukan intervensi terhadap berita yang ditulis oleh wartawan. Hal serupa juga tertera dalam Pasal 4 Kode Etik Jurnalistik bahwa wartawan Indonesia menolak imbalan yang dapat mempengaruhi obyektivitas pemberitaan. (KEJ, 2006).Oleh karenanya, diperlukan kerjasama yang baik antara praktisi public relations dan wartawan sehingga uang amplop tidak mempengaruhi pemberitaan.

"Misalnya begini, kalau ada berita yang negatif tentang institusi pendidikan mereka, jangan menutup akses wartawan untuk melakukan liputan. Seharusnya praktisi public relations bisa menyediakan list nomor telepon narasumber yang kredibel untuk dihubungi oleh wartawan.” (wawancara dengan Haris Firdaus)

Dalam Kode Etik Jurnalistik yang pernah dicetuskan oleh Society of Professional Journalists disebutkan bahwa kewajiban wartawan untuk mengawal kepentingan bersama dengan cara mencari kebenaran dan mengakomodasi event dan isu-isu secara fair. Integritas profesional adalah landasan dari kredibilitas wartawan (SPJ Convention, 1996). Hal ini juga sesuai dengan pasal 11 dalam Kode Etik Jurnalistik yang menyebutkan bahwa wartawan Indonesia meneliti kebenaran bahan berita dan memperhatikan kredibilitas sertakompetensi sumber berita (KEJ, 2006). Artinya, wartawan dalam melakukan peliputan harus mengkroscek 
kredibilitas narasumbernya. Dalam kaitannya dengan media relations dengan praktisi public relations, wartawan bisa memanfaatkan link yang disediakan oleh praktisi public relations untuk mengambil data mengenai isu yang ditulisnya.

"Praktisi public relations sering tidak langsung tanggap dengan wartawan. Seringkali tidak jelas siapa yang harus diwawancara oleh wartawan. Kalau mengundang wartawan paling tidak harus ada fasilitas wawancara".(wawancara dengan Pristiqa A.Wirastami)

Kerjasama antara wartawan dan praktisi public relations seperti yang dicetuskan oleh waratawan Tribun di atas seharusnya bisa menjadi masukan bagi praktisi public relations dalam melakukan media relations. Apabila ada kerjasama yang baik antara praktisi public relations dan wartawan tentunya akan mencegah pemberian amplop kepada wartawan karena pada akhirnya praktisi public relations dan wartawan mempunyai peran yang saling menguntungkan.

\section{Strategi Pengolahan Isu dan Layak Berita}

Dalam pemberitaan jurnalistik, ada yang namanya nilai berita. Adanya nilai berita inilah yang membuat sebuah informasi menjadi layak berita. Beberapa nilai berita tersebut antara lain newsworthy (kepentingan), timeliness (kebaruan), magnitude(skala), proximity(kedekatan), prominance(keterkenalan) dan human interest(nilai kemanusian). Wartawan dalam mencari berita pasti berdasarkan nilai-nilai berita. Karena itu, praktisi public relations seharusnya bisa mengandalkan nilai berita untuk menarik wartawan agar mau meliput institusinya

"Kadang-kadang isu tidak dimanfaatan dan ditangkap oleh praktisi public relations padahal banyak isu yang bisa menjadi wacana public. Isu pendidikan khususnya, harus menarik, tidak hanya seputar event sajatetapi juga kasus-kasus hangat yang membu- tuhkan pendapat dari kalangan pendidik." (wawancara dengan Haris Firdaus)

Pernyataan di atas menunjukkan bahwa biasanya praktisi public relations hanya memanfaatkan wartawan sebagai sarana publikasi event yang diadakan oleh institusi mereka. Dengan memahami dan memanfaatkan nilai berita, praktisi public realtions bisa mempromosikan event mereka dengan cara yang menarik bagi wartawan dan pembaca.Event universitas bisa dicari dari nilainilai beritanya, tidak hanya timeliness-nya tapi juga nilai-nilai lain seperti human interest. Contohnya,pemberitaan event wisuda sebuah perguruan tinggi, ada wartawan yang mengambil angle berita bukan dari seremonialnya melainkan dari angle salah satu wisudawati yang datang ke acara wisuda menaiki becak. Hal ini tentunya lebih bernilai berita daripada sekadar berita acara wisuda saja. Praktisi public relations seharusnya bisa mencari hal-hal menarik dari event yang diadakan institusinya dan memberikannya kepada wartawan.

"Praktisi public relations sebenarnya bisa bermain dengan isu, misalnya kasus Hello Kitty yang sempat mencuat kemarin bisa diangkat dari sisi pendidikan dengan memasukkan pendapat pakar yang terkait dari universitas. Ini sebenarnya termasuk cara cerdas untuk mempublikasikan universitas tersebut kepada pembaca." (wawancaradengan Laela Rohmatin).

Pernyataan tersebut sesuai dengan jurnal yang ditulis oleh Steve M. Barkin yang menyebutkan bahwa wartawan bisa berperan sebagai pencerita, bukan hanya sebagai pelapor saja. Barkin menulis, pemberitaan oleh seorang wartawan bisa memperkuat pandangan mengenai realitas sosial. Wartawan juga mempunyai peran dalam menegaskan dan mempertahankan tatanan sosial (Barkin, 1989: 32). Hal ini juga sesuai dengan Pasal 2 dalam Kode Etik Jurnalistik yang menyebutkan bahwa wartawan Indonesia menempuh cara-cara yang profesional dalam melaksanakan tugas jurnalistik (KEJ, 2006). Artinya, 
wartawan harus menghasilkan berita yang faktual dan jelas sumbernya. Di sini wartawan bisa memanfaatkan hubungan dengan praktisi public relations agar dapat memberikan akses kepada pakar-pakar terkait dalam institusi mereka. Dalam kaitannya dengan institusi pendidikan tinggi, praktisi public relations juga bisa menyediakan isu pendidikan yang terkait.

"Kelemahan praktisi public relations itu adalah mereka belum punya strategi untuk mengolah isu supaya orang tertarik untuk membacanya, misalnya isupenelitian yang dilakukan dosen dan mahasiswa. Sering kali praktisi public relations hanya memberikan isuevent kunjungan atau wisuda saja. Padahal isu penelitian yang berbau akademis justru lebih menarik bagi wartawan." (wawancara dengan Laela Rohmatin)

Menurut Wendy Bacon, kegiatan jurnalistik sebenarnya adalah bidang yang besar yang bisa menyerap dan merubah batas-batas yang ada, terutama yang berkaitan dengan bidang komunikasi (Bacon, 149). Artinya, wartawan bisa memanfaatkan bidang public relations dalam mencari pemberitaannya. Selama ini release yang diberikan oleh praktisi public relations yang diberikan kepada wartawan hanya tentang wisuda, kunjungan dan prestasi institusi saja, release tentang isu pendidikan dan penelitian malah tidak ada. Terjadi pertentangan di kalangan wartawan yang harus jauh-jauh hanya untuk melihat event seperti wisuda.Wartawan sebenarnya membutuhkan isu untuk menjadi berita, tetapi praktisi public relations hanya asal menyodorkan isu demi kepentingan institusi saja.

\footnotetext{
"Selain release dan pressconference yang harus dilakukan oleh praktisi public relations adalah publikasi penelitian, seperti UAD pernah mengundang wartawan untuk mendengarkan cerita mahasiswa yang menyelesaikan thesis di Thailand." (wawancara dengan Pristiqa A.Wirastami)
}

Dengan memberikan release mengenai kegiatan kependidikan seperti penelitian yang dilakukan oleh dosen atau pun pertukaran mahasiswa, sebenarnya secara tidak langsung praktisi public relations juga mempublikasikan institusinya melalui pemberitaan yang dilakukan oleh wartawan. Di sini wartawan mempunyai berita menarik untuk ditulis yang bernilai berita tinggi dan praktisi public relations menunaikan tugas publikasinya. Selain itu, media relations pun terjalin dengan baik dan sehat.

\section{Praktek Budaya Amplop dan Kode Etik Jurnalistik}

Sebenarnya, dalam Kode Etik Jurnalistik, peraturan mengenai pemberian amplop sudah diatur meskipun tidak secara eksplisit menyatakan "amplop". Dalam penafsiran Pasal 1 Kode Etik Jurnalistik yang menyebutkan wartawan Indonesia bersikap independen, menghasilkan berita yang akurat, berimbang, dan tidak beritikad buruk, independen ditafsirkan bahwa wartawan memberitakan peristiwa atau fakta sesuai dengan suara hati nurani tanpa campur tangan, paksaan, dan intervensi dari pihak lain termasuk pemilik perusahaan pers (KEJ, 2006). Artinya, pemberian amplop oleh praktisi public relations kepada wartawan dianggap sebagai intervensi dari pihak luar yang dapat mempengaruhi berita yang ditulis oleh wartawan.

\begin{abstract}
"Menerima amplop sebenarnya adalah kebiasaan dan akhirnya menjadi simbiosis mutualisme dengan praktisi public relations. Selain itu, menerima amplop itu tergantung wartawannya masing-masing.Kadang wartawan justru saling mengingatkan." (wawancara dengan Pristiqa A.Wirastami)
\end{abstract}

Dari pernyataan di atas, sebenarnya tidak semua wartawan menerima amplop yang disediakan oleh praktisi public relations. Ketika institusi pendidikan tinggi menyelenggarakan sebuah event biasanya praktisi public relations menyediakan amplop untuk diberikan kepada wartawan yang hadir dalam event tersebut. Meskipun demikian, tidak semua wartawan mengambil amplop yang dise- 
diakan dan tidak semua praktisi public relations menyediakan amplop dengan maksud mengintervensi pemberitaan wartawan.

"Ada kesalahan mindset di beberapainstitusi pendidikan tinggi tentang semua isu yang ada harus dimuat karena menyangkut promosi dan eksistensi institusi." (wawancara dengan Laela Rohmatin)

Pernyataan di atas memperkuat pendapat mengenai strategi mengolah isu agar bisa menghindari pemberian amplop. Seharusnya wartawan dan praktisi public relations bisa saling bersinergi karena pada dasarnya wartawan butuh isu. Dengan demikian tanpa amplop pun wartawan akan mau menulis berita yang menjadi publikasi. Asalkan praktisi public relations bisa mengolah isu yang ada, hal itu bisa dilakukan.

"Praktisi public relations harus bisa mengolah isu dalam kacamata media sehingga amplop tidak lagi diperlukan. Budaya amplop muncul karena ada gap antara isu public relations dan isu media." (wawancara dengan Laela Rohmatin)

Artinya, dalam beberapa isu sebenarnya wartawan menolak tetapi praktisi public relations tetap memaksa. Jadi akhirnya pemberian amplop ini adalah untuk membeli independensi wartawan, karena praktisi public relations tidak percaya diri dengan pemberitaannya.Sebenarnya penting bagi praktisi public relations untuk mempelajari kaedahkaedah jurnalistik sehingga bisa membuat isu yang layak menjadi berita bagi wartawan. Hal ini dikarenakan, wartawan dan praktisi public relations membutuhkan isu untuk dijual, sehingga tanpa amplop wartawan akan tetap mencari isu dan praktisi public relations akan mendapatkan publikasi dari isu tersebut.

"Wartawan tidak butuh amplop karena sebenarnya wartawan membutuhkan praktisi public relations untuk menyehatkan wartawan." (wawancara dengan Laela Rohmatin)
Mengenai tanggapan institusi media tempat wartawan bekerja, terdapat beberapa pandangan menarik mengenai budaya amplop dari hasil wawancara yang dilakukan. Ada media yang dengan tegas memberikan punishment, namun ada juga yang masih memberikan kelonggaran

"Kompas jelas melarang, meski belum pernah menemukan kasus amplop, tetapi bila ada wartawan yang menerima amplop pasti dikeluarkan karena itu berkaitan dengan kejujuran." (wawancara dengan Haris Firdaus)

Dari pernyataan wartawan tersebut terlihat bahwa Kompas tidak mentoleransi adanya budaya amplop di kalangan wartawannya, bahkan tidak segan-segan memberikan sanksi pemecatan. Sikap Kompas ini sangat sesuai dengan Pasal 6 Kode Etik Jurnalistik bahwa wartawan Indonesia tidak menyalahgunakan profesi dan tidak menerima suap (KEJ, 2006). Amplop di sini diasosiasikan dengan suap karena dapat berpengaruh dengan independensi wartawan dalam menulis berita. Bentuk suap atau amplop pun bisa bermacam-macam, tidak hanya uang tapi juga jenis gratifikasi lain seperti barang atau fasilitas dari pihak lain di luar wartawan.

Lain halnya dengan Tribun, meskipun anak perusahaan dari Kompas, namun sanksi yang diberikan kepada wartawan amplop tidak begitu keras. Beberapa kasus yang lalu bahkan sering kali dibiarkan. Walaupun sekarang sudah ada sanksi terhadap wartawan amplop, tetapi dalam pemberian sanksi masih melalui tahapan-tahapan sebelum sampai pada sanksi pemecatan.

"Penanganan Tribunmasih kurang, padahal harusnya ikut peraturan Kompas, tetapi prakteknya ada wartawan yang menerima. Dulu sering tidak mendapat sanksi, sekarang pimred akan ditegur, bila ketahuan jabatan akan diturunkan."

Sedangkan di Harian Jogja, diperlukan bukti untuk bisa memberi sanksi kepada wartawan amplop. Artinya, bila seorang wartawan dicurigai menerima amplop tidak ser- 
ta merta diberi sanksi.

"Di Harjo, berkaitan dengan amplop, harus ada bukti baru bisa ditindak." (wawancara dengan Laela Rohmatin)

Berdasarkan hasil wawancara-wawancara di atas, permasalan budaya amplop di kalangan wartawan seharusnya bisa dihindari. Meskipun demikian ada penafsiran independensi wartawan dalam pasal 1 Kode Etik Jurnalistik yang bisa menjadi celah bagi wartawan untuk melanggar independensinya. Di situ disebutkan bahwa independen berarti memberitakan peristiwa atau fakta sesuai dengan suara hati nurani tanpa campur tangan, paksaan, dan intervensi dari pihak lain termasuk pemilik perusahaan pers (KEJ, 2006). Perkataan hati nurani dalam pasal tersebut sering disalahartikan bahwa kekuatan Kode Etik Jurnalistik hanya pada hati nurani tanpa adanya sanksi yang tegas bagi wartawan yang melanggarnya. Untuk itu, selain penghapusan budaya amplop dari kalangan wartawan dan praktisi public relations, juga diperlukan penegasan aturan dalam Kode Etik Jurnalistik yang ada.

\section{SIMPULAN DAN SARAN}

\section{Kesimpulan}

Relasi yang baik antara wartawan dan praktisi public relations dapat mencegah budaya amplop pada wartawan. Ketika praktisi public relations dan wartawan sama-sama memahami kebutuhan kedua belah pihak, akhirnya dapat tercipta kerjasama yang baik. Pada dasarnya wartawan membutuhkan isu dari praktisi public relations dan praktisi public relations memerlukan wartawan untuk publikasi.

Pengolahan isu menjadi hal penting agar menghasilkan berita yang menarik. Wartawan mengharapkan praktisi public relations dapat memberikan isu yang memiliki nilai berita sehingga bisa dikonsumsi oleh masyarakat. Event sederhana yang ada sebenarnya bisa diolah menjadi berita apabila dilihat dari kacamata wartawan.

Tidak semua wartawan mau menerima amplop, bahkan banyak yang tidak setuju dengan budaya amplop karena hal tersebut bertentangan dengan pasal-pasal yang terdapat dalam Kode Etik Jurnalistik. Selain itu, pemberian amplop juga dapat mempengaruhi objektivitas wartawan dalam mencari berita.

\section{Saran}

Praktisi public relations seharusnya mempelajari kaedah-kaedah jurnalistik untuk membantu media relations yang dilakukannya dengan wartawan.

Institusi media perlu memberlakukan sanksi tegas kepada wartawan yang melakukan budaya amplop.

Perlunya peninjauan ulang terhadap pasal-pasal yang ada dalam Kode Etik Jurnalistik. Maka dari itu, penelitian selanjutnya, bisa dilakukan dengan cara melakukan wawancara pada wartawan amplop untuk lebih memahami mengenai fenomena budaya amplop. 


\section{DAFTAR PUSTAKA}

\section{BUKU-BUKU}

Kovach, Bill dan Tom Rosenstiel, 2001, The Elements of Journalism: What Newspeople Should Know and the Public Should Expect, United States, Crown Archetype.

\section{JURNAL}

Bacon, Wendy, 2006, Journalism as Research, Australian Journalism Review, Vol 28 (2), p147-157

Barkin, Steve M., 1989, Journalist as Storyteller: An Interdiciplinary Perspective, American Journalism, Vol. 1 (2), p27

\section{PERATURAN PERUNDANG-UNDANGAN}

Kode Etik Jurnalistik (2006)

Society of Profetional Journalists Convention (1996) 